\title{
The Arnold Berliner Award 2016
}

\author{
Sven Thatje ${ }^{1}$
}

Received: 5 June 2016 / Accepted: 6 June 2016 / Published online: 10 June 2016

(C) Springer-Verlag Berlin Heidelberg 2016

The recipient of this year's Arnold Berliner Award (Thatje 2013) is Dr Juan Scheun (National Zoological Gardens, Pretoria, South Africa), in recognition of his research article on the South African lesser bushbaby (Galago moholi) published in The Science of Nature in 2015 (Scheun et al. 2015). The study formed part of his doctoral degree, which he obtained from the University of Pretoria in South Africa.

In the habitat of the African forest and bushlands, the African lesser bushbaby is of nocturnal living and has a mostly solitary lifestyle. For most of the year, it sustains itself by feeding on insects, and it supplements its diet with the sugar-rich gum of the acacia tree, as well as fruits. When urbanised, the availability of sugar-rich food sources drives the lesser bushbaby to abandon its mostly solitary lifestyle. When offered a variety of food, the bushbaby prioritises feeds such as yoghurt, cat food, bread and exotic fruits such as pineapple, over insects and acacia gum. The fight for food at a feeding spot comes at the cost of an increased level of stress in

Sven Thatje

svth@noc.soton.ac.uk

Ocean and Earth Science, National Oceanography Centre Southampton, University of Southampton, Southampton SO14 3ZH, UK response to social interactions. Females dominate this temporary social group structure, which is abandoned during the day when individuals find rest further away from the feeding ground. Another fundamental change to the species' ecology within an urban environment is the movement of bushbabies as pairs or groups of up to ten specimens. Having access to sugar-rich food in excess, however, may come at a potential cost: a monitored urban population of the lesser bush baby showed significantly higher body mass values compared to their rural counterparts, the long-term effects of which on their ecology and physiology remain to be investigated.

The Arnold Berliner Award was established in recognition of the founding editor of Naturwissenschaften (now The Science of Nature, Thatje 2013) who led the journal for the exceptionally long period of 22 years. The award is sponsored by Springer and is given annually for the best research article published in The Science of Nature during the previous calendar year (Thatje 2012). Criteria are excellence in science, originality, as well as aspects of interdisciplinarity, overall mirroring Arnold Berliner's motivation for initiating the journal. A jury, consisting of the board of editors and the editor-in-chief, selects the awardee. The award is marked with the Arnold Berliner Award Medal (Figs. 1 and 2) and is accompanied by a biennial subscription to the electronic edition of The Science of Nature, a 500-euro voucher for Springer books, as well as a cash prize of 250 euros. 


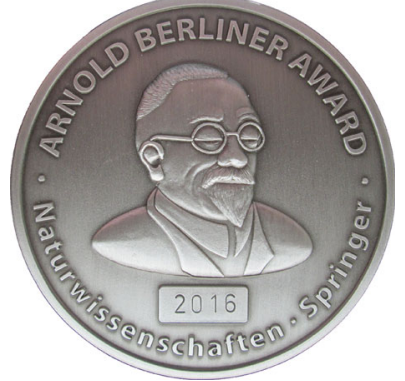

Fig. 1 The Arnold Berliner Award Medal. Arnold Berliner (1862-1942) was the founding editor of The Science of Nature and the journal's editorin-chief from 1913-1935 (Thatje 2012, 2013)

\section{References}

Scheun J, Bennett NC, Ganswindt A, Nowack J (2015) The hustle and bustle of city life: monitoring the effects of urbanisation of the African lesser bushbaby. Sci Nat 102:57. doi:10.1007/s00114-015$1305-4$

Thatje S (2012) Introducing the Arnold Berliner Award. Naturwissenschaften 99(9):675-676

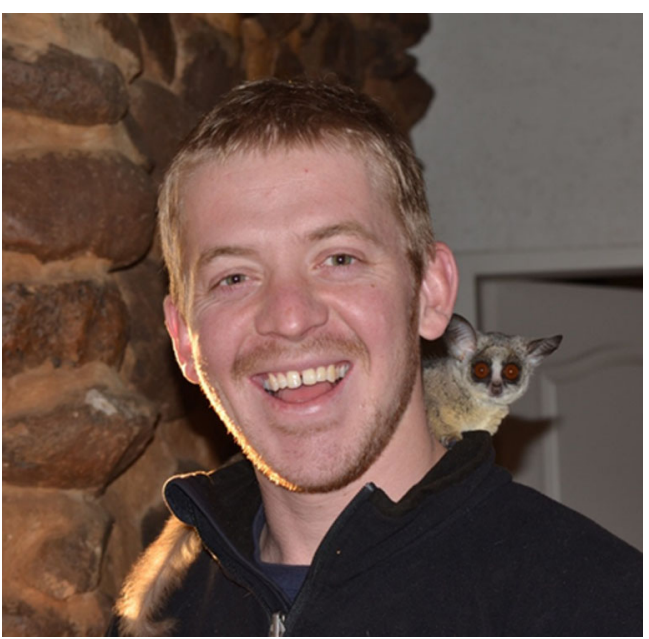

Fig. 2 Dr Juan Scheun, winner of the Arnold Berliner Award 2016

Thatje S (2013) Dr Arnold Berliner (1862-1942); physicist and founding editor of Naturwissenschaften. Naturwissenschaften 100:11051107 